Brazilian Journal

of Chemical

ISSN 0104-6632

Engineering

\title{
ON-LINE MONITORING OF BIOMASS CONCENTRATION BASED ON A CAPACITANCE SENSOR: ASSESSING THE METHODOLOGY FOR DIFFERENT BACTERIA AND YEAST HIGH CELL DENSITY FED-BATCH CULTURES
}

\author{
A. C. L. Horta ${ }^{1 *}$, A. J. da Silva ${ }^{1}$, C. R. Sargo ${ }^{1}$, I. D. Cavalcanti-Montaño ${ }^{1}$, \\ C. A. Galeano-Suarez ${ }^{1}$, A. M. Velez ${ }^{1}$, M. P. Santos ${ }^{1}$, V. M. Gonçalves ${ }^{2}$, \\ R. C. Giordano ${ }^{1}$ and T. C. Zangirolami ${ }^{1}$ \\ ${ }^{1}$ Universidade Federal de São Carlos, Departamento de Engenharia Química, \\ P.O. Box 676, Zip Code: 13565-905, São Carlos - SP, Brazil. \\ Phone: (55) (16) 3351-8264; Fax: 55 16-3351-8266 \\ E-mail: horta@ufscar.br \\ ${ }^{2}$ Centro de Biotecnologia, Instituto Butantan, São Paulo - SP, Brazil.
}

(Submitted: May 30, 2014 ; Revised: August 12, 2014 ; Accepted: January 9, 2015)

\begin{abstract}
The performance of an in-situ capacitance sensor for on-line monitoring of biomass concentration was evaluated for some of the most important microorganisms in the biotechnology industry: Escherichia coli, Saccharomyces cerevisiae, Pichia pastoris and Bacillus megaterium. A total of 33 batch and fed-batch cultures were carried out in a bench-scale bioreactor and biomass formation trends were followed by dielectric measurements during the growth phase as well as the induction phase, for 5 recombinant $E$. coli strains. Permittivity measurements and viable cellular concentrations presented a linear correlation for all the studied conditions. In addition, the permittivity signal was further used for inference of the cellular growth rate. The estimated specific growth rates mirrored the main trends of the metabolic states of the different cells and they can be further used for setting-up control strategies in fed-batch cultures.
\end{abstract}

Keywords: Capacitance probe; E. coli; S. cerevisiae; P. pastori; B. megaterium; Specific growth rate.

\section{INTRODUCTION}

Undoubtedly, reliable on-line measurements of biomass concentration are the most important information for running a fed-batch culture. Continuous measurement of cell concentration is technically feasible by means of several techniques such as laser turbidimetry, suspended solid concentration analysis, in situ microscopy, near-infrared spectroscopy, laser light scattering analysis, fluorescence, flow cytometry, dielectric spectroscopy and capacitance measurements, as well as with optical density scanners (Yamane et al., 1991; Macaloney et al., 1997; Xiong et al., 2008; Kiviharju et al., 2008; Dabros et al., 2009; Díaz et al., 2010; Downey et al., 2014; Wyre and Overton, 2014).

Among the above mentioned alternatives, dielectric spectroscopy is one of the most popular biomass sensors and has been applied so far to monitor biomass formation in submerged cultures of different organisms like stem cells, animal cells, plant cells, Escherichia coli, Saccharomyces cerevisiae, Lactobacillus casei, Streptomyces sp., among others

*To whom correspondence should be addressed 
(Cannizzaro et al., 2003; Arnoux et al., 2005; Ferreira et al., 2005; Maskov et al., 2008; Reis et al., 2009; Knabben et al., 2010; Justice et al., 2011; Horta et al., 2012; Bryant et al., 2011; Justice et al., 2011; Wajgali et al., 2013).

The capacitance probe working principle is based on the polarization of the cell membrane when placed in an ionic solution and subjected to an alternating electric field. Ion movement within the highly conducting cellular cytoplasm is restricted by the nonconductive cellular membrane and each cell will act as a capacitor. The polarization charge is measured by the capacitance of the solution, and the cell polarization is a function of the electric field frequency. At low frequencies $(<0.1 \mathrm{MHz})$, cell membranes are completely polarized and the capacitance of the solution is high. As the excitation frequency increases up to $10 \mathrm{MHz}$, the capacitance will decrease due to the incomplete cellular polarization. At high electric field frequencies $(>10 \mathrm{MHz})$, there is not enough time for complete cell polarization and only small particles are polarized. The magnitude of the membrane polarization is directly proportional to the volume that it encapsulates. Hence, the dielectric permittivity is directly proportional to the viable biomass concentration, since dead cells do not present polarization in their membranes (Davey and Kell, 1998; Markx and Davey, 1999).

The possibility of assessing the physiological state of the cells through the dielectric properties of cell suspensions is a very important feature when capacitance probes are used for monitoring genetically modified organisms (Matanguihan et al., 1994). Usually strong promoters are used for heterologous protein production in host cells, exposing them to a stressful condition after induction takes place. This problem has been widely described for recombinant protein expression in E. coli under the control of T7lac and $\lambda$ promoters (Khalilzadeh et al., 2003; Shiloach and Fass, 2005; Norsyahida et al., 2009) and the main consequences are: viability loss, growth cessation or even cell death, acetate production and substrate accumulation.

In addition, since dielectric permittivity measurements are sensitive to cell viability, they can be used for recognition of physiological changes during the cultivation (Markx and Davey, 1999; Kiviharju et al., 2008; Maskow et al., 2008), like the Crabtree effect in yeast cultures (Davey et al., 1996); overflow metabolism in E. coli fermentations (Knabben et al., 2010) and spore formation in Bacillus or fungi cultivations (Sarrafzadeh et al., 2005).

Given on-line capacitance measurements, the probe signal can be correlated to viable cell concentration. Furthermore, once on-line inferred biomass concentration data are available, they can be used in several applications, including the on-line estimation of the specific growth rate and the control of feeding flow rate in fed-batch cultures (Dabros et al., 2010; Horta et al., 2012; Horta et al., 2014).

This work presents a discussion of the use of a permittivity biomass sensor in batch and fed-batch cultures of 4 different microorganisms, with the following objectives: i) evaluate the performance of a capacitance sensor for on-line estimation of biomass concentrations of four different microorganisms; ii) estimate on-line values of the specific growth rates from the raw permittivity signal provided by the capacitance sensor.

\section{MATERIALS AND METHODS}

\section{Microorganisms and Cultivation Media}

Different wild and recombinant microorganisms were used in the studies:

i) Bacillus megaterium: Strain PV361 was gently donated by Prof. Patricia S. Vary, Northern Illinois University. PV361 is a variant of the strain QMB1551, where the genes of its seven constitutive megaplasmids were deleted (Silva, 2001).

ii) Five different clones of Escherichia coli BL21(DE3) were studied. The first one, called $E$. coli "a", expresses a fragment of the antigenic surface protein SpaA from Erysipelothrix rhusiopathiae (Silva et al., 2012, 2013). The second, third and forth clones, called E. coli "b", "c" and "e", produces fragments of the antigenic surface proteins PspA clade 1, 3 and 4 from Streptococcus pneumoniae (Carvalho et al., 2012; Sargo, 2011; Santos, 2012) and were kindly provided by Dr. Eliane Miyaji and Dr. Luciana Cerqueira Leite (Centro de Biotecnologia, Instituto Butantan, São Paulo, Brazil). The fifth clone, called E. coli "d", transformed with the plasmid pT101/DTOPO with pac gene codifying for penicillin G acylase (PGA) production (Montes et al., 2007), was kindly donated by the Laboratório de Biocatálisis, ICP-CSIC-Madri, Spain.

iii) Recombinant cells of Pichia pastoris GS115 (Invitrogen USA) expressing $\alpha$-amylase from $B$. subtilis were kindly provided by Prof. Fernando Torres (University of Brasilia) (Macauley-Patrick et al., 2005; Araújo, 2008; Burke et al., 2000).

iv) Saccharomyces cerevisiae: batches and fedbatches were carried out with fresh baker's yeast.

Modified complex auto-induction media formulations (Studier, 2005, Silva et al., 2012, Santos, 2012), containing yeast extract and Tryptone or Phytone ${ }^{\circledR}$ as nitrogen sources and glycerol, glucose and 
lactose as carbon sources, were used in cultivations of E. coli "a" and "e"; a modified defined HDF medium (Seeger et al., 1995; Sargo, 2011) was used in cultivations of $E$. coli "b" and "c" and both media were used for cultivations of $E$. coli "d" (Vélez et al., 2014). Commercial $S$. cerevisiae was cultivated in complex medium containing glucose $(10 \mathrm{~g} / \mathrm{L})$ as main carbon source and $\mathrm{KH}_{2} \mathrm{PO}_{4}(5.0 \mathrm{~g} / \mathrm{L}),\left(\mathrm{NH}_{4}\right)_{2} \mathrm{SO}_{4}$ $(4.5 \mathrm{~g} / \mathrm{L}), \mathrm{MgSO}_{4}(0.5 \mathrm{~g} / \mathrm{L})$ and yeast extract $(30 \mathrm{~g} / \mathrm{L})$. Recombinant $P$. pastori was cultivated in complex medium containing yeast extract and peptone as complex nutrients and glucose as main carbon source (Montano, 2010). B. megaterium was also cultivated in complex SNB and LB media, supplemented or not with cheese whey (Suárez, 2010).

\section{Bioreactor Operation, Instrumentation and Auto- mation}

The cultivations were conducted in a $5 \mathrm{~L}$ (in-house) bioreactor monitored by SuperSys_HCDC® (Horta et al., 2011, 2014). The $\mathrm{pH}$ was controlled (on/off) at 6.7 (E. coli), 6.5 (Pichia pastoris) and 7.5 (Bacillus megaterium) (pHmeter GLI PRO) by addition of $\mathrm{H}_{3} \mathrm{PO}_{4}$ and $\mathrm{NH}_{4} \mathrm{OH} 30 \%$ (v/v). Temperature was set at $27{ }^{\circ} \mathrm{C}$ for Saccharomyces cerevisae, $30{ }^{\circ} \mathrm{C}$ for Bacillus megaterium, E. coli " $b$ " and " $c$ " and " $e$ " as well as for Pichia pastoris. E. coli " $a$ " was cultivated at $37{ }^{\circ} \mathrm{C}$ and $E$. coli "d" at $20{ }^{\circ} \mathrm{C}$ (induction phase). Dissolved oxygen concentration (DOC) was monitored by a Mettler Toledo probe Inpro 6800, connected to a $\mathrm{CE} \mathrm{O}_{2} 4050$ transmitter, and kept at $30 \%$ of its saturation limit $(20 \%$ for Bacillus megaterium) by a hybrid controller which automatically changed both agitation speed (between 200 and 900 rpm) and the composition of the gas stream supplied to the bioreactor (by mixing pure oxygen with air). The DOC calibration (100\%) was done at the beginning of the experiment, before inoculation. The gas stream supplied to the bioreactor was a mixture of air and pure oxygen and its total flow rate was maintained at $6 \mathrm{~L} / \mathrm{min}$ by two mass flow controllers (GFC AALBORG). The exhaust gas composition was assessed by a Sick/Maihak S.710 $\mathrm{CO}_{2}$ and $\mathrm{O}_{2}$ analyzer. The broth permittivity and conductivity were monitored by a biomass sensor from FOGALE® Nanotech. On-line data acquisition, as well as monitoring/control of all instruments via a compact field point 2020 (cFP-2020, National Instruments), was performed by the software SuperSys_HCDC ${ }^{\mathrm{R}}$ developed in LabView ${ }^{\circledR}$.

The feeding supply was provided by an Ismatec BVP pump following the exponential profile given by equation 1 (Nielsen et al., 2002).

$$
\mathrm{F}=\left(\frac{\mu}{Y_{X S}}+\mathrm{m}\right) \cdot \frac{\mathrm{C}_{\mathrm{X} 0} \cdot \mathrm{V}_{0}}{\mathrm{C}_{\mathrm{S} 0}-\mathrm{C}_{\mathrm{SR}}} \cdot \mathrm{e}^{\left(\mu_{\mathrm{SET}} \cdot \mathrm{t}\right)}
$$

In Equation (1), $\mathrm{F}\left(\mathrm{Lh}^{-1}\right)$ is the feed flow rate, $\mu_{\mathrm{SET}}\left(\mathrm{h}^{-1}\right)$ is the desired specific growth, $\mathrm{Y}_{\mathrm{XS}}(\mathrm{g}$ DCW $\left.\mathrm{g}_{\text {glycerol }}{ }^{-1}\right)$ is the biomass yield coefficient on glycerol or glucose, $\mathrm{m}\left(\mathrm{g} D C W \mathrm{~g}_{\text {glycerol }}{ }^{-1} \mathrm{~h}^{-1}\right)$ is the maintenance coefficient, $\mathrm{C}_{\mathrm{X} 0}\left[\mathrm{~g}(\mathrm{DCW}) \mathrm{L}^{-1}\right]$ and $\mathrm{V}_{0}(\mathrm{~L})$ correspond to the cellular concentration and volume, respectively, at the beginning of the fed-batch phase, $\mathrm{C}_{\mathrm{S} 0}\left(\mathrm{~g}_{\text {glycerol }} \mathrm{L}^{-1}\right)$ is the carbon source concentration in the supplementary medium and $\mathrm{C}_{\mathrm{SR}}\left(\mathrm{g}_{\text {glycerol }} \mathrm{L}^{-1}\right)$ represents the residual carbon source (glycerol or glucose) concentration.

The exponential feed profile changed according to the cultivated microorganism. For B. megaterium and $P$. pastoris, a pre-defined feeding profile with $\mu_{\mathrm{SET}}$ equal to $0.12 \mathrm{~h}^{-1}$ was used. For $E$. coli, different feeding strategies were studied, including predefined feeding profiles at $\mu_{\text {SET }}$ equal to $0.13 \mathrm{~h}^{-1}$ (E. coli " $a$ ") and $0.3 \mathrm{~h}^{-1}$ (E. coli " $b$ "). In addition, cultivations of $E$. coli "a", "b", "c" and "d" were also carried out using an advanced controller for the feeding flow rate given by Eq. (1), where the parameters $\mu_{\mathrm{SET}}$, Yxs e m were continuously and automatically retuned at each $10 \mathrm{~min}$ interval using the values of $\mathrm{C}_{\mathrm{X}}$ and $\mu$ obtained online from the permittivity measurements provided by the capacitance biomass sensor (Horta et al., 2012). For E. coli "e", the cultivation was carried out in batch mode using an autoinduction strategy (Santos, 2012).

\section{Analytical Methods}

Biomass concentration in the samples withdrawn during the cultivations was measured by optical density readings at $\lambda=600 \mathrm{~nm}$. Biomass concentration was also assessed by the dry cell weight method. Metabolite concentrations and carbon source consumption were measured by High Performance Liquid Chromatography (HPLC) as described in Silva et al. (2008). Glycerol and glucose were also measured by enzymatic kits (Laborlab, Brazil) (Silva et al., 2013; Sargo, 2011).

\section{On-Line Biomass Inference and Specific Growth Rate Estimation}

During all cultivations, online biomass monitoring by a capacitance sensor (BIOMASS System Viable cell density monitoring - FOGALE nanotech) was carried out. A reference frequency of $10 \mathrm{MHz}$ was used as blank signal, to compensate disturbances 
caused by changes in the medium composition and in the overall bioreactor environment (agitation, aeration, presence of debris etc). The frequency of measurement was set at $2.076 \mathrm{MHz}$ for yeast and 2.984 $\mathrm{MHz}$ for bacterial cultivations. The response signal at the reference frequency was automatically subtracted from the signal at the frequency of measurement (Fogale, 2014).

The probe response was transferred to the computer database via its analog output, in an acquisition period of one second. These data were used for online estimation of biomass concentration and specific growth rate as briefly described in the following. A detailed description of data treatment, including pseudocodes equations and calculations, is available in Horta et al. (2012).

Permittivity data was acquired as a 0.004-0.02 Ampere (A) analog signal from the Fogale Nanotech Instrument and multiplied by a calibration factor proportional to the instrument output range to convert the readings in $\mathrm{A}$ to $\mathrm{pF} / \mathrm{cm}$. This analog signal was noisy and it had to be treated first by a smoothed moving average (SMA) filter to be used as input in the calibration curve relating the smoothed permittivity to cellular concentration $\left(\mathrm{g}_{\mathrm{DCW}} / \mathrm{L}\right)$. The SMA filter is a variation of the classical moving average (CMA) filter. While the CMA filter assumes the value of the average of the rough data vector, SMA uses the average of the smoothed data array instead, leading to smaller smoothing window sizes (n) and shorter processing time. In this work, the SMA filter was implemented with the following n values: 40 ( $E$. coli), 50 ( $S$. cerevisiae and $P$. pastoris), 110 (B. megaterium). The smoothed permittivity output from the SMA filter, combined with mass balance equations for batch and fed-batch cultivations, was also used to estimate the specific growth rate $(\mu)$. The estimated raw $\mu$ data were further treated by a SMA filter to improve its smoothness (Horta et al., 2012).

\section{RESULTS AND DISCUSSION}

\section{Correlation Between Permittivity and Cell Con- centration - Cx On-Line Estimation}

The growth of microorganisms with different sizes, shapes and physiological states was on-line monitored by permittivity measurements.

The correlation between permittivity and cellular concentration can be observed in Figure 1 for Bacillus megaterium, Saccharomyces cerevisiae, Pichia pastoris and Escherichia coli_a and in Figure 2 for the recombinant Escherichia coli strains a, b, c, and d.

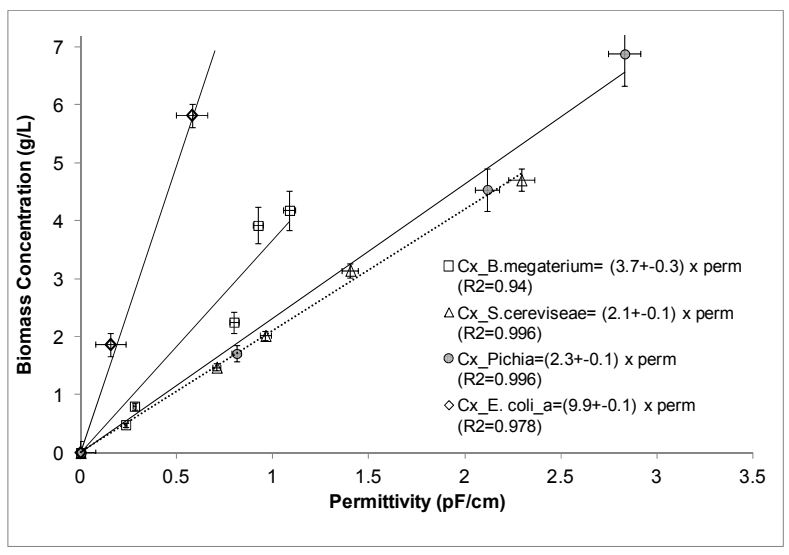

Figure 1: Correlation between permittivity [Perm $(\mathrm{pF} / \mathrm{cm})]$ and cellular concentration $[\mathrm{Cx}(\mathrm{gDCW} / \mathrm{L})]$ for B. megaterium, S. cerevisiae, $P$. pastoris and $E$. coli. Symbols correspond to experimental data, lines correspond to linear fits.

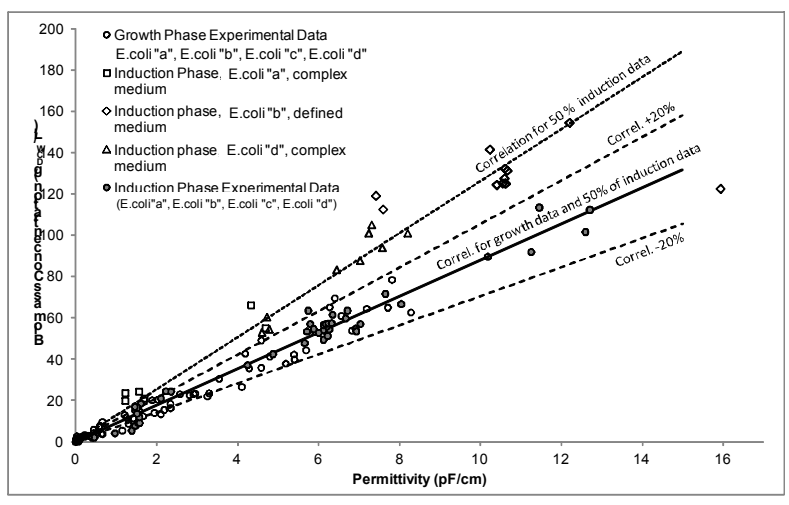

Figure 2: Correlation between permittivity [Perm $(\mathrm{pF} / \mathrm{cm})]$ and cellular concentration $\left[\mathrm{Cx}\left(\mathrm{g}_{\mathrm{DCW}} / \mathrm{L}\right)\right]$ for different recombinant Escherichia coli strains. Symbols correspond to experimental data, lines correspond to linear fits.

It can be seen in Figure 1 and Figure 2 that the correlation of permittivity and cellular concentration changes according to each microorganism, as expected. Good fits and very similar correlations were obtained for yeast cells, whose average diameters are in the ranges of 5 to $10 \mu \mathrm{m}$ for $S$. cerevisiae and 1 to $2.2 \mu \mathrm{m}$ for $P$. pastoris. Yet, the correlation parameters for $B$. megaterium and $E$. coli were rather different, reflecting the differences between these two bacteria in cell size ( $E$. coli has a total volume of $\sim 1$ $\mu^{3}$; B. megaterium cell volume is $\sim 60 \mu^{3}$ ) and cell wall composition (B. megaterium is Gram positive, E. coli is Gram negative).

From the huge amount of available data for the 4 different $E$. coli clones grown in different media, for concentrations ranging from 0.5 to $150 \mathrm{gDCW} / \mathrm{L}$, a 
deep analysis of the capacitance sensor performance can be made. Thus, comparing E. coli "a", "b", "c" and " $d$ " cultures, it can be noticed from Figure 2 that changes in temperature and medium composition do not cause significant deviations between permittivity and cellular concentration. In fact, the unique correlation reproduced in Eq. (2) could be used to estimate biomass concentration for all strains during the growth phase. We can also observe significant scattering for biomass concentrations lower than 20 $\mathrm{g}_{\mathrm{DCW}} / \mathrm{L}$ due to the lack of accuracy of permittivity measurements within this range.

On the other hand, $50 \%$ of the data belonging to the induction phase could not be described by Eq. (2) and the new correlation given by Eq. (3) was generated to fit these data. Comparing the coefficients of Eqs. (2) and (3), it can be noticed that the slope increases during the induction phase. This phenomenon, not mentioned in the literature, is caused by the loss of cell viability associated with the stress caused by heterologous protein synthesis. Since non-viable cells do not contribute to the permittivity, the capacitance probe precisely reflected the change in cell physiology taking place during the induction phase (Silva et al., 2013). This change is not detected by conventional optical density or dry weight measurements, which cannot distinguish viable and non-viable cells. Because of this mismatch between the two methodologies, a new correlation relating dry cell weight measurements to permittivity is required.

$$
\begin{aligned}
& \mathrm{Cx}=(8.8 \pm 0.1) \cdot \operatorname{Perm}\left(\mathrm{R}^{2}=0.989\right) \\
& \mathrm{Cx}=(12.6 \pm 0.2) \cdot \operatorname{Perm}\left(\mathrm{R}^{2}=0.984\right)
\end{aligned}
$$

It is also interesting to notice that half of the induction phase data is described by Eq. (2) (Group 1) while the other half is described by Eq. (3) (Group 2). Group 1 contains the experimental points belonging to the beginning of induction. For all the cases discussed here, the production of heterologous protein was triggered by inducer addition, which can be IPTG or lactose. Shortly after inducer addition, the cells have not yet undergone drastic metabolic changes, which explains the validity of Eq. (2). Group 1 also includes $85 \%$ of the experimental points from the cultivations carried out with E. coli "a" and "d" in complex media. It has been suggested in the literature that medium supplementation with amino acids or proteins can partially relieve the stress caused by the recombinant protein production (Shiloach and Fass, 2005; Shojaosadati et al., 2008; Tripathi et al., 2009). On the other hand, Group 2 consists mainly of data from E. coli "b" and "c" cultures, which were carried out in defined media. In these cases, the metabolic effort to produce the recombinant protein from basic medium components (glycerol, ammonia and salts) was significantly higher, impairing cell viability.

Figure 3 presents the validation of the correlation between biomass and the permittivity signal for 2 batch cultivations of $E$. coli_e in complex medium, carried out with 2 different nitrogen sources (Phytone ${ }^{\circledR}$ and Tryptone). As can be seen from Figure 3, the biomass concentration estimated from the permittivity signal by Eq. (2), which was obtained from E. coli "a", "b", "c" and "d" data, shows an excellent agreement $\left(\mathrm{R}^{2}=0.93\right.$ and 0.95$)$ with the cell concentration determined by dry weight measurements.
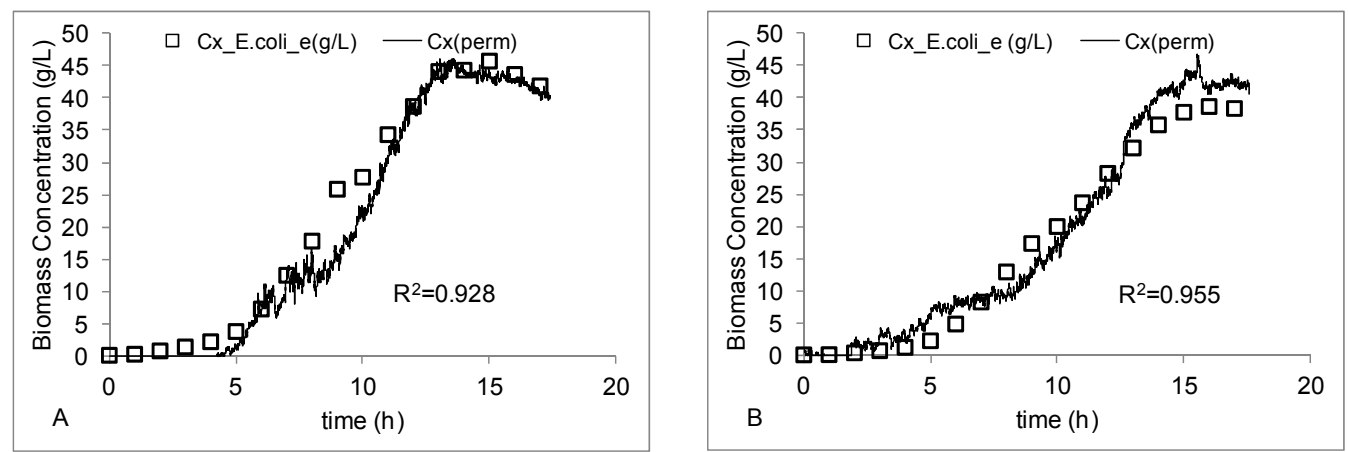

Figure 3: Biomass growth profile during Escherichia coli_e batch cultures (Santos, 2012). $\mathrm{Cx}($ perm) is the biomass estimated from the permittivity signal using Equation (2) $\left(\mathrm{Cx}=8.8^{*}\right.$ perm); and $\mathrm{Cx}$ is the cellular concentration $\left(\mathrm{g}_{\mathrm{DCW}} / \mathrm{L}\right)$. A: using Tryptone. B: using Phytone ${ }^{\circledR}$. 


\section{On-Line Growth Rate Estimation}

As shown previously, reliable correlations between viable cell concentrations and permittivity data can be set-up for all cases studied. On-line permittivity signals can also be employed for inferring the specific growth rate, after being subjected to the appropriate treatment with a SMA filter to improve their smoothness (Horta et al, 2012).

Figure 4 compares both raw and smoothed permittivity data and presents the on-line $\mu$ values estimated from the smoothed permittivity for the microorganisms studied. The estimated $\mu$ curve followed closely the cell growth pattern, but the $\mu$ data were still too noisy, even after being treated with a SMA filter.

The amplitude of the oscillations was generally higher in the first 5-10 h of cultivation. As explained previously, a significant scattering on the estimated biomass concentration is caused by the low precision of the capacitance probe for measuring permittivity values below $\sim 1 \mathrm{pF} / \mathrm{cm}$. The mathematical manipulation to estimate $\mu$ also contributed to amplify the noise. Time course oscillation of $\mu$ was also reported by other researchers (Xiong et al., 2008; Davey et al., 1996; Ferreira et al., 2005) and, according to Davey et al. (1996), this oscillatory behaviour can also be caused by continuous readout.

This noise in the $\mu$ signal (in the early hours) presents no problems for the human analysis of growth profiles, but the $\mu$ signal cannot be used to control the feed flow rate without a new filter. Neverthless, the feed supply is usually started at higher biomass concentrations, where the inferred $\mu$ tends to be more stable (Panes A, C and G for $\mathrm{t}>20$, 14 and $12 \mathrm{~h}$, respectively).
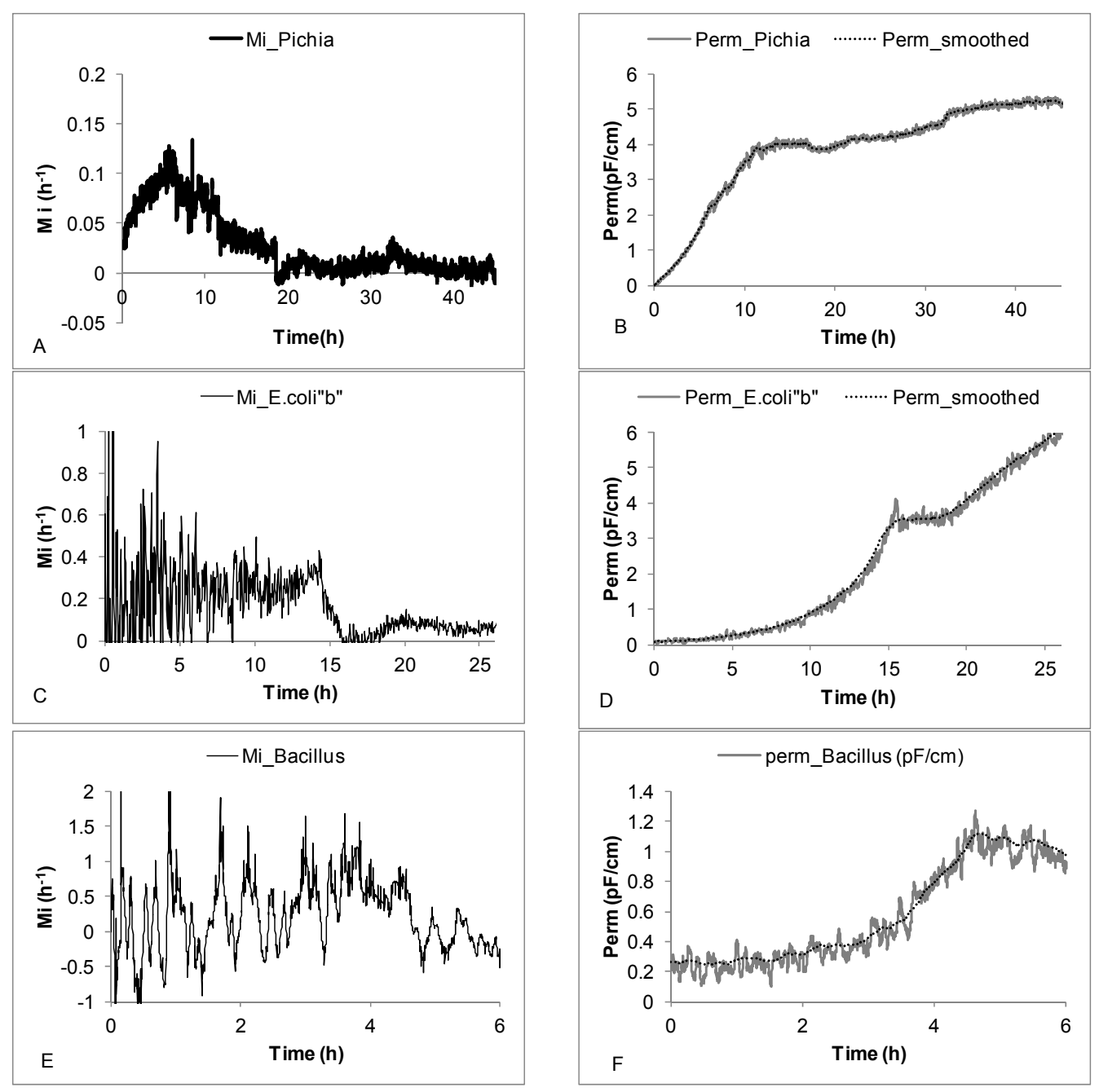

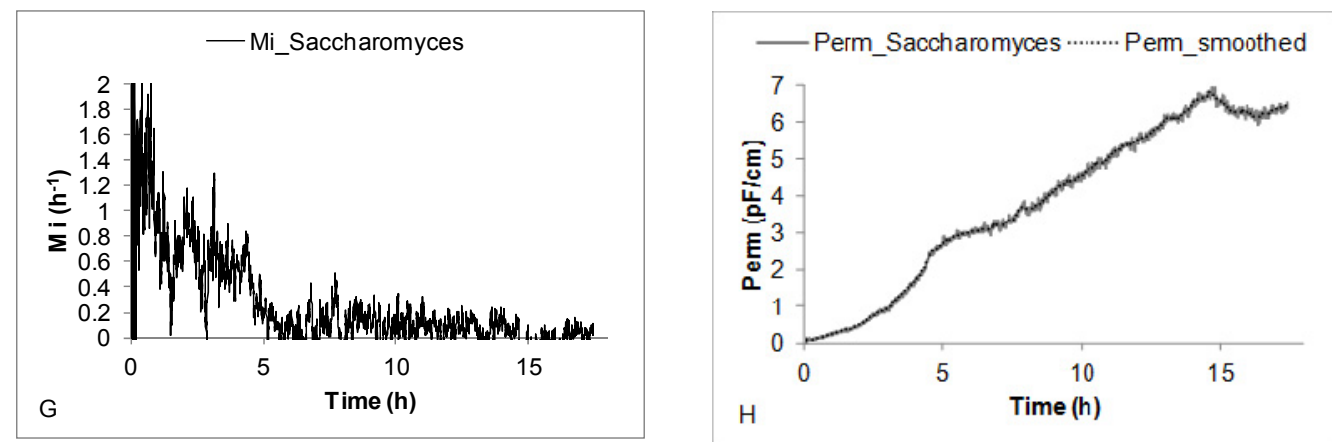

Figure 4: A, C, E, G: $\mu\left(\mathrm{h}^{-1}\right)$ calculated online from smoothed permittivity $(\mathrm{pF} / \mathrm{cm}) ; \mathrm{B}, \mathrm{D}, \mathrm{F}$, $\mathrm{H}$ : permittivity (continuous line) and smoothed permittivity (dotted line); I, J: biomass concentration in dry weight (point), and calculated by the permittivity signal. A and B: Pichia pastoris (Montaño, 2010). C and D: Escherichia coli "b". E and F: Bacillus megaterium (Suárez, 2010). G and H: Saccharomyces cerevisiae.

Besides the on-line inference of specific growth rate, which can be used for monitoring or updating $\mu_{\mathrm{SET}}$ via Eq. (1), the metabolic changes well reproduced by permittivity data can also be applied to improve the tuning of other parameters in the same equation. During the induction phase, cell metabolism is driven to foreign protein production. Therefore, the assumption of approximately constant values for the maintenance $(\mathrm{m})$ and biomass yield (Yxs) coefficients in Eq. (1) does not hold any more. In fact, Yxs decreases and $\mathrm{m}$ increases along the induction phase and these changes need to be incorporated into Eq. (1) for a better control of the bioprocess (Horta et al., 2012).

\section{CONCLUSIONS}

The capacitance sensor proved to be a reliable tool for on-line biomass monitoring during cultivation of different kinds of microorganisms, including Gram-positive and Gram-negative bacteria and the two yeasts mainly used nowadays in the biotechnology industry, $S$. cerevisiae and P. pastoris. After filter processing steps, the permittivity data collected allowed on-line following of the biomass formation and estimation of the specific growth rate during the cultivation process.

For recombinant E. coli cultures, the drastic changes occurring during the induction phase were clearly indicated by permittivity measurements. The analysis of permittivity data helped to understand the influence of media composition and the induction period on the cell response to the stress caused by protein expression. They also could be used to assess the influence of other factors, such as tem- perature and type of inducer, during the protein production phase.

The inference of on-line specific growth rate can certainly contribute to improving the control of the growth rate and of the bioprocess as a whole. Based on the present results, a dynamic control of the exponential growth rate by maintaining the feeding rate at optimal levels in fed-batch processes was developed and implemented for $\mathrm{r} E$. coli high cell density cultivations (Horta et al., 2012). This technology is part of the monitoring and control software SUPERSYS_HCDC ${ }^{\circledR}$ developed and registered (Horta et al., 2011) by the researchers from the Laboratory of Development and Automation of Bioprocesses, Department of Chemical Engineering of Federal University of São Carlos, Brazil.

\section{ACKNOWLEDGEMENTS}

The authors thank the Brazilian research-funding agencies: Fundação de Amparo à Pesquisa do Estado de São Paulo (FAPESP), Conselho Nacional de Desenvolvimento Científico e Tecnológico (CNPq) and Financiadora de Estudos e Projetos (FINEP).

\section{REFERENCES}

Araújo, J., Production of chymosin B from Bos taurus in Pichia pastoris. University of Brasilia. Dissertation (2008).

Burke, D., Dawson, D., Stearns, T., Methods in Yeast Genetics: A Laboratory Course Manual. (Cold Spring Harbor Lab. Press, Plainview, NY) (2000). 
Carvalho, R. J., Cabrera-Crespo, J., Tanizaki, M. M., Gonçalves, V. M., Development of production and purification processes of recombinant fragment of pneumococcal surface protein A in Escherichia coli using different carbon sources and chromatography sequences. Appl. Microbiol. Biotechnol., 94, 683-694 (2012).

Dabros, M., Schuler, M. M., Marison, I. W., Simple control of specific growth rate in biotechnological fed-batch processes based on enhanced online measurements of biomass. Bioprocess Biosyst. Eng., 33, 1109-1118 (2010).

Davey, H. M., Davey, C. L., Woodward, A. M., Edmonds, A. N., Lee, A. W., Kell, D. B., Oscillatory, stochastic and chaotic growth rate fluctuations in permittistatically controlled yeast cultures. Biosyst., 39, 43-61 (1996).

Díaz, M., Herrero, M., García, L. A., Quirós, C., Application of flow cytometry to industrial microbial processes. Biochemical Engineering Journal, 48(3), 385-407 (2010).

Downey, B. J., Graham, L. J., Breit, J. F., Glutting, N. K., A novel approach for using dielectric spectroscopy to predict viable cell volume (VCV) in early process development. Biotechnol. Progress, 30, 479-487 (2014).

Ferreira, A. P., Vieira, L. M., Cardoso, J. P., Menezes, J. C., Evaluation of a new annular capacitance probe for biomass monitoring in industrial pilotscale fermentations. J. Biotechnol., 116, 403-409 (2005).

Fogale Nanotech: Biomass System, <http://www. fogale.fr/ biotech/pages/home.php> Accessed July 09, 2014 (2014).

Horta, A. C. L., Sargo, C. R., Silva, A. J., Gonzaga, M. S., Gonçalves, V. M., Zangirolami, T. C., Giordano, R. C., Intensification of high cell density cultivations of $\mathrm{r} E$. coli for production of $S$. pneumoniae antigenic surface protein, PspA3, using modelbased adaptive control. Bioprocess Biosyst. Eng., 35, 1269-1280 (2012).

Horta, A. C. L., Silva, A. J., Sargo, C. R., Velez, A. M., Gonzaga, M. C., Giordano, R. C., Gonçalves, V. M., Zangirolami, T. C., A supervision and control tool based on artificial intelligence for high cell density cultivations. Brazilian Journal of Chemical Engineering, 31, 457-468 (2014).

Horta, A. C. L., Zangirolami, T. C., Giordano, R. C., Cruz, A. J. G., Reis, G. B., Jesus, C. D. F., Supervisory system for bioreactor high cell density cultivations. Software Registration Proc. 11008-6 INPI, Brazil. (2011).

Kiviharju, K., Salomen, K., Moilanen, U., Eerikainen, T., Biomass measurement online: The performance of in situ measurements and software sensors. J. Ind. Microbiol. Biotechnol., 35, 657-665 (2008).

Macauley-Patrick, S., Fazenda, M. L., Mcneil, B., Harvey, L. M., Heterologous protein production using the Pichia pastoris expression system. Yeast, 22, 249-270 (2005).

Markx, G. H., Davey, C. L., The dielectric properties of biological cells at radiofrequencies: Applications in biotechnology. Enzym Microb. Technol., 25, 161-171 (1999).

Maskow, T., Röllich, A., Fetzer, I., Yao, J., Harms, H., Observation of non-linear biomass-capacitance correlations: Reasons and implications for bioprocess control. Biosens. Bioelectron., 24, 123-128 (2008).

Montaño, I. D. C., Otimização Dinâmica do Cultivo Semi-contínuo de Pichia pastoris recombinante para produção de enzimas heterólogas. Dissertação de Mestrado, PPG-EQ, UFSCar (2010). (In Portuguese).

Montes, T., Grazú, V., López-Gallego, F., Hermoso, J. A., Garcia, J. L., Manso, I., Galán, B., González, R., Fernandez-Lafuente, R., Guisán, J. M., Genetic modification of the Penicillin G Acylase surface to improve its reversible immobilization on ionic exchangers. Appl. Environ. Microb., 73, 312-319 (2007).

Nielsen, J., Villadsen, J., Lidén, G., Bioreaction Engineering Principles. 2nd Ed., Kluwer Academic/ Plenum Publishers, New York (2002).

Reis, G. B., Horta, A. C. L., Zangirolami, T. C., Giordano, R. C., Cruz, A. J. G., Control of fedbatch yeast cultivation using a capacitance sensor. 10th International Symposium on Process Systems Engineering: Part A Computer Aided Chemical Eng., 27, 1323-1328 (2009).

Santos, M. P., Avaliação da temperatura de indução e de fontes de Nitrogênio na produção de proteína de superfície de Streptococcus pneumoniae em Escherichia coli recombinante. Dissertação de Mestrado - Programa de Pós-graduação em Engenharia Química - Universidade Federal de São Carlos (2012). (In Portuguese).

Sargo, C. R., Aperfeiçoamento de cultivos de alta densidade celular de rE.coli utilizando glicerol como fonte de carbono. Dissertação de Mestrado - Programa de Pós-graduação em Engenharia Química - Universidade Federal de São Carlos (2011). (In Portuguese).

Sarrafzadeh, M. H., Belloy, L., Esteban, G., Navarro, J. M., Ghommidh, C., Dielectric monitoring of growth and sporulation of Bacillus thuringiensis. Biotechnol. Letters, 27, 511-517 (2005). 
Seeger, A., Schbeppe, B., Mccarthy, J. E. G., Deckwer, W. D., Rinas, U., Comparison of temperature and isopropyl- $\beta$-D-thiogalacto-pyranosideinduced synthesis of basic fibroblast growth factor in high-cell-density cultures of recombinant Escherichia coli. Enz. Microb. Tech., 17, 947953 (1995).

Shiloach, J., Fass, R., Growing E. coli to high cell density: a historical perspective on method development. Biotechnol. Adv., 23, 345-357 (2005).

Shojaosadati, S. A., Kolaei, S. M. V., Babaeipour, V., Farnoud, A. M., Recent advances in high cell density cultivation for production of recombinant protein. Iranian J. Biotech., 6, 63-84 (2008).

Silva, A. J., Horta, A. C. L., Velez, A. M., Iemma, M. R. C., Sargo, C. R., Giordano, R. L. C., Novo, M. T. M., Giordano, R. C., Zangirolami, T. C., Nonconventional induction strategies for production of subunit swine erysipelas vaccine antigen in $\mathrm{r} E$. coli fed-batch cultures. SpringerPlus, 2, 322 (2013).

Silva, A. J., Baptista-Neto, A., Cilento, M. C., Giordano, R. C., Zangirolami, T. C., Bioreactor aeration conditions modulate growth and antigen expression during Erysipelothrix rhusiopathiae cultivation. Appl. Microbiol. Biotechnol., 79, 2331(2008).

Silva, A. J., Iemma, M. R. C., Horta, A. C. L., Sargo, C. R., Giordano, R. L. C., Giordano, R. C., Zangirolami, T. C., Novo, M. T. M., Cloning, autoinduction expression, and purification of $\mathrm{rSpaA}$ swine erysipelas antigen. Curr. Microbiol., 65, 369-374 (2012).

Silva, M., Lopes, A. P. Y., Gamberini, M., Schenkman, R. P., Ramos, C. R., Ho, P. L., Leite, L. C. C., Improved expression of PsaA from Strepto- coccus pneumoniae in E. coli and its purification. In: Reunião Anual da Sociedade Brasileira de Bioquímica, 2001, Caxambu (2001).

Suárez, C. A. G., Otimização do cultivo de Bacillus megaterium recombinante em bateladas alimentadas. Dissertação de Mestrado, PPG-EQ, UFSCar (2010). (In Portuguese).

Studier, F. W., Protein production by auto-induction in high-density shaking culture. Protein Express Purif., 41, 207-234 (2005).

Tripathi, N. K., Sathyaseelan, K., Jana, A. M., Rao, P. V. L., High yield production of heterologous proteins with Escherichia coli. Defence Sci. J., 59(2), 137-146 (2009).

Vélez, A. M., Silva, A. J., Horta, A. C. L., Sargo, C. R., Campani, G., Gonçalves Silva, G., Giordano, R. L. C., Zangirolami, T. C., High-throughput strategies for penicillin $G$ acylase production in $\mathrm{r} E$. coli fed-batch cultivations. BMC Biotechnology (Online), 14, 6 (2014).

Wajgali, A. E., Esteban, G., Fournier, F., Pinton, H., Marc, A., Impact of microcarrier coverage on using permittivity for on-line monitoring high adherent Vero cell densities in perfusion bioreactors. Biochemical Engineering Journal, 70, 173179 (2013).

Wyre, C., Overton, T. W., Flow cytometric analysis of $E$. coli on agar plates: Implications for recombinant protein production. Biotechnol. Lett., 36, 1485-1494 (2014).

Xiong, Z. Q., Guo, M. J., Guo, Y. X., Chu, J., Zhuang, Y. P., Zhang, S. L., Real-time viable-cell mass monitoring in high-cell-density fed-batch glutathione fermentation by Saccharomyces cerevisiae T65 in industrial complex medium. J. Biosci. Bioeng., 105(4), 409-413 (2008). 